A PCPDTTPD-based narrow bandgap conjugated polyelectrolyte for organic solar cells

Peer-reviewed author version

BREBELS, Jeroen; KESTERS, Jurgen; Defour, Maxime; PIROTTE, Geert; Van Mele, Bruno; MANCA, Jean; LUTSEN, Laurence; VANDERZANDE, Dirk \& MAES, Wouter (2018) A PCPDTTPD-based narrow bandgap conjugated polyelectrolyte for organic solar cells. In: POLYMER, 137, p. 303-311.

DOI: 10.1016/j.polymer.2018.01.027

Handle: http://hdl.handle.net/1942/27911 


\section{A PCPDTTPD-based narrow bandgap conjugated polyelectrolyte for organic}

solar cells

Jeroen Brebels, ${ }^{a}$ Jurgen Kesters, ${ }^{a}$ Maxime Defour, ${ }^{b}$ Geert Pirotte, ${ }^{a}$ Bruno Van Mele, ${ }^{b}$ Jean Manca, ${ }^{c}$ Laurence Lutsen, ${ }^{d}$ Dirk Vanderzande, ${ }^{a, d}$ and Wouter Maes $* a, d$

(a) UHasselt - Hasselt University, Institute for Materials Research (IMO-IMOMEC), Design \& Synthesis of Organic Semiconductors (DSOS), Agoralaan, 3590 Diepenbeek, Belgium

(b) Physical Chemistry and Polymer Science (FYSC), Vrije Universiteit Brussel (VUB), Pleinlaan 2, 1050 Brussels, Belgium

(c) UHasselt - Hasselt University, X-LAB, Agoralaan, 3590 Diepenbeek, Belgium

(d) IMEC, Associated lab IMOMEC, Wetenschapspark 1, 3590 Diepenbeek, Belgium

Corresponding author: Tel.: +32 11268312; E-mail: wouter.maes@uhasselt.be 


\begin{abstract}
Extensive research on organic photovoltaics has granted impressive power conversion efficiencies, nowadays exceeding $13 \%$ for state-of-the-art photoactive material combinations. Nevertheless, different strategies can be adopted to further enhance the efficiency and the competitiveness with alternative photovoltaic technologies. Conjugated polyelectrolytes have been applied as anode or cathode interlayers to optimize ohmic contacts and lower the contact resistance, thereby improving the ultimate device efficiency. Here, we present an interlayer material belonging to the emerging class of narrow bandgap conjugated polyelectrolytes, based on an imidazolium functionalized $4 H$-cyclopenta[2,1-b:3,4$b^{\prime}$ ]dithiophene (CPDT) as the electron-rich polymer building block and $4 H$-thieno[3,4c]pyrrole-4,6(5H)-dione (TPD) as the electron-deficient subunit. The ionic polymer is applied as cathode interlayer for PBDTTPD:[70]PCBM (poly[bis(2'-ethylhexyloxy)benzo[1,2- $b: 4,5-$ $b^{\prime}$ ]dithiophene-alt- $N$-octylthieno[3,4-c]pyrrole-4,6-dione]:[6,6]-phenyl-C ${ }_{71}$-butyric acid methyl ester) bulk heterojunction polymer solar cells, improving the overall device performance from 6.9 to $7.8 \%$.
\end{abstract}

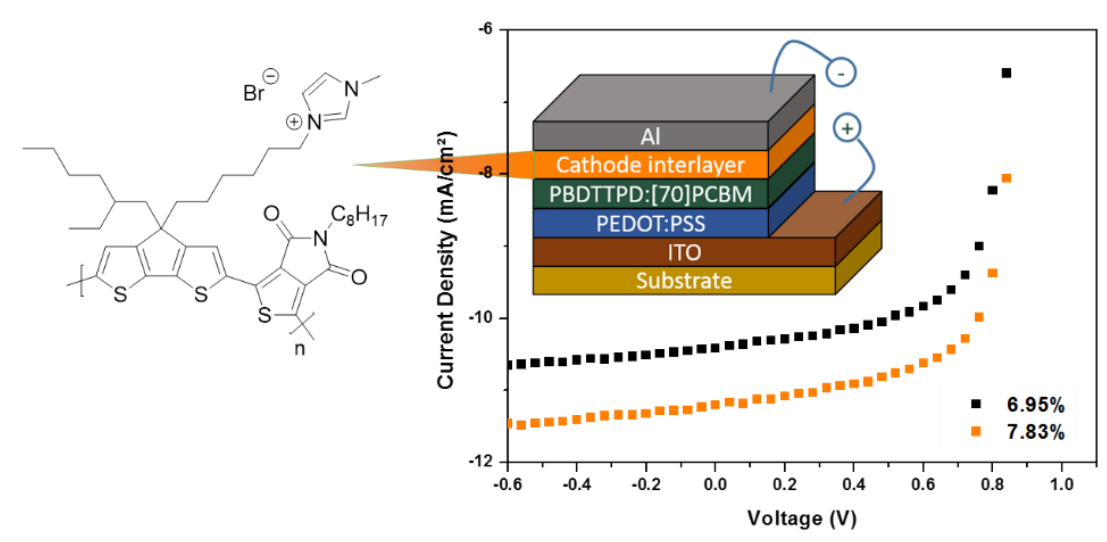

\title{
Keywords
}

narrow bandgap conjugated polyelectrolytes; cathode interlayers; organic solar cells 


\section{Introduction}

Organic photovoltaics (OPV's) have witnessed a strong growth over the last two decades as a promising technology to convert solar irradiation into electricity. ${ }^{[1-4]}$ In contrast to their siliconbased counterparts, fully flexible and light-weight devices can be targeted via large-area production methods and with a reduced cost. ${ }^{[5-8]}$ On the active organic material side, strong efforts have been directed toward the development of new low bandgap materials (polymers as well as small molecules) that optimally match with the solar spectrum. ${ }^{[9,10]}$ Furthermore, perfect frontier orbital (HOMO and LUMO) energy level alignment of the electron donor and acceptor materials combined in the bulk heterojunction (BHJ) blend and an optimal interpenetrating nanostructured $\mathrm{BHJ}$ morphology are required to maximize the device performance. ${ }^{[11,12]}$ This has resulted in power conversion efficiencies (PCE's) nowadays exceeding $13 \%$ for the best donor-acceptor combinations. ${ }^{[13-15]}$ An important point of attention is the efficient charge extraction of the created excitons upon light absorption because of the inherent recombination processes present in (blends of) organic materials. ${ }^{[16,17]}$ BHJ OPV devices typically consist of different layers stacked on top of each other (vide infra). Interface engineering is hence of utmost importance to realize ohmic contacts (with low contact resistance) of the photoactive layer with the metal electrodes and to improve the selectivity of charge transport. ${ }^{[18]}$ Recent studies in this direction have demonstrated the high potential of interface engineering to reduce charge accumulation and to increase charge extraction, enhancing the device performance. ${ }^{[19-21]}$

Conjugated polyelectrolytes (CPE's), combining a conjugated polymer backbone with ionic (mostly side chain) groups, have already proven to be successful as cathode and anode modification layers to boost the photovoltaic performance of OPV and hybrid organicinorganic (perovskite) devices. ${ }^{[22-25]}$ Furthermore, the pending polar groups give rise to additional interesting features. An inherent benefit of creating more hydrophilic polymers is their processability from more environmentally friendly, low-boiling solvents (e.g. alcohols). ${ }^{[23,26]}$ The detailed working principle of CPE interlayers is, however, not always fully understood, in particular with respect to the structural features giving rise to the observed improvements of the different photovoltaic output parameters. So et al. investigated the effect of different interlayers for diverse systems and summarized the different roles these interlayers have. ${ }^{[17]}$ They found that the interlayers control i) the electrode-polymer energy alignment, ii) the built-in electric field, iii) the surface energy, and iv) the surface recombination. Furthermore, interlayers are also applied to prevent penetration of the thermally evaporated electric contact (e.g. Al) into the organic layer. Most importantly, CPE's serve as a simple and powerful tool to enhance the OPV device parameters. ${ }^{[22]}$ The opencircuit voltage $\left(V_{\text {oc }}\right)$ often improves, mainly because of a higher built-in potential created by the hydrophilic surface and better dipole alignment. The fill factor (FF) also increases due to the ohmic contact with more balanced charge injection and better charge carrier transportation and collection at the respective electrode, hence also improving the shortcircuit current density $\left(J_{\mathrm{sc}}\right) .^{[18-20,22,27]}$ 
For the design of cathode interlayers, it is preferable to have a low work function and good (thermal) stability. Most CPE's are derived from polythiophenes (often functionalized P3HT derivatives) or polyfluorenes (e.g. PFN). ${ }^{[28]}$ Although PFN is the most commonly used CPE interlayer material, polythiophenes have recently shown slightly better device performances. ${ }^{[21-23,29-31]}$ A drawback of these CPE's is their tendency to not uniformly distribute on top of the active layer when spin-coated, leading to the formation of clusters. ${ }^{[21,23]}$ Narrow bandgap conjugated polyelectrolytes (NBGCPE's) are an emerging class of CPE's, aiming to combine the advantages of conjugated low bandgap polymers (e.g. improved compatibility, ${ }^{[32]}$ conductivity ${ }^{[33]}$ and charge carrier mobilities ${ }^{[34,35]}$ ) and CPE interlayer materials. In 2013, the group of Bazan was the first to demonstrate that NBGCPE's can exhibit superior characteristics (e.g. charge transport properties) as compared to conventional CPE's. ${ }^{[34,35]}$ Nevertheless, very limited research has been devoted to these types of CPE's, likely because of the synthetic efforts required. ${ }^{[32-37]}$

In the current manuscript, the concept of ionic side chain functionalization to achieve NBGCPE's has been translated to a 'push-pull' system based on $4 H$-cyclopenta[2,1-b:3,4$b^{\prime}$ ]dithiophene (CPDT) as the donor and 1,3-dibromo-4H-thieno[3,4-c]pyrrole-4,6(5H)-dione (TPD) as the acceptor building block. As such, we demonstrate that the incorporation of an imidazolium functionalized PCPDTTPD-based low bandgap copolymer as cathode interlayer (on top of a poly[bis(2'-ethylhexyloxy)benzo[1,2-b:4,5- $b^{\prime}$ ]dithiophene-alt- $N$-octylthieno[3,4c]pyrrole-4,6-dione]:[6,6]-phenyl- C $_{71}$-butyric acid methyl ester (PBDTTPD:[70]PCBM) active layer) leads to an enhancement of the overall OPV device efficiency with $13 \%$ (from 6.9 to $7.8 \%)$.

\section{Results and discussion}

\section{Material synthesis and characterization}

To prepare the PCPDTTPD interlayer material, a Stille polycondensation approach was envisaged, combining the distannylated CPDT precursor with a dibrominated TPD. For the synthesis of the CPDT monomer, different literature procedures were combined to come up with a simplified reaction sequence providing good yields (Scheme 1). ${ }^{[38-41]}$ The first step in the reaction sequence was the synthesis of 3,3'-dibromo-2,2'-bithiophene (2) via the Gronowitz dithienyl synthesis. ${ }^{[38]}$ 3-Bromothiophene (1) was lithiated at the 2-position with lithium diisopropylamide (LDA), followed by coupling with the aid of $\mathrm{CuCl}_{2}$. Next, a cyclization reaction was performed in the presence of $\mathrm{N}, \mathrm{N}$-dimethylcarbamoyl chloride, yielding $4 \mathrm{H}$ cyclopenta[2,1-b:3,4- $\left.b^{\prime}\right]$ dithiophen-4-one (3). ${ }^{[39]}$ The synthesis of precursor 4 then involved a Wittig-type reaction, in which the carbonyl group of compound $\mathbf{3}$ was converted into an exocyclic double bond with $n$-BuLi and 2-ethylhexylphosphonium bromide. ${ }^{[40,41]}$ An alcohol functionalized side chain was then introduced in the next step in a one pot reductionsubstitution reaction. However, an unwanted side product appeared in this reaction. After NMR and mass analysis, it turned out to be compound 6, lacking 2 carbon atoms in the functionalized side chain. Further studies on this reaction showed that the tetrahydrofuran 
(THF) solvent used for the reaction ring-opened and was attached to precursor 4 . This hypothesis was confirmed through the introduction of other cyclic ethers under the same reaction conditions. 2-Methyltetrahydrofuran (MeTHF) and oxetane were also incorporated when used as solvents for this reaction. Incorporation of larger cyclic ethers was not possible, probably because of their low ring strain, providing less driving force for the ring opening reaction (Scheme 2). Although only minor amounts of the unwanted side product (up to 10\%) were obtained, it still poses problems in the next reaction steps. Due to their structural similarity, purification is not straightforward. Different solvents were then tested and methyltert-butylether (MTBE) turned out to be a good substitute, providing a satisfying yield. The alcohol functionality of precursor $\mathbf{5}$ was then converted into a bromine group by an Appel reaction. In the final step, lithiation and subsequent stannylation were performed to afford the CPDT monomer 8. To enhance the purity of the stannylated monomer, (recycling) preparative size exclusion chromatography (prep-SEC) was performed.
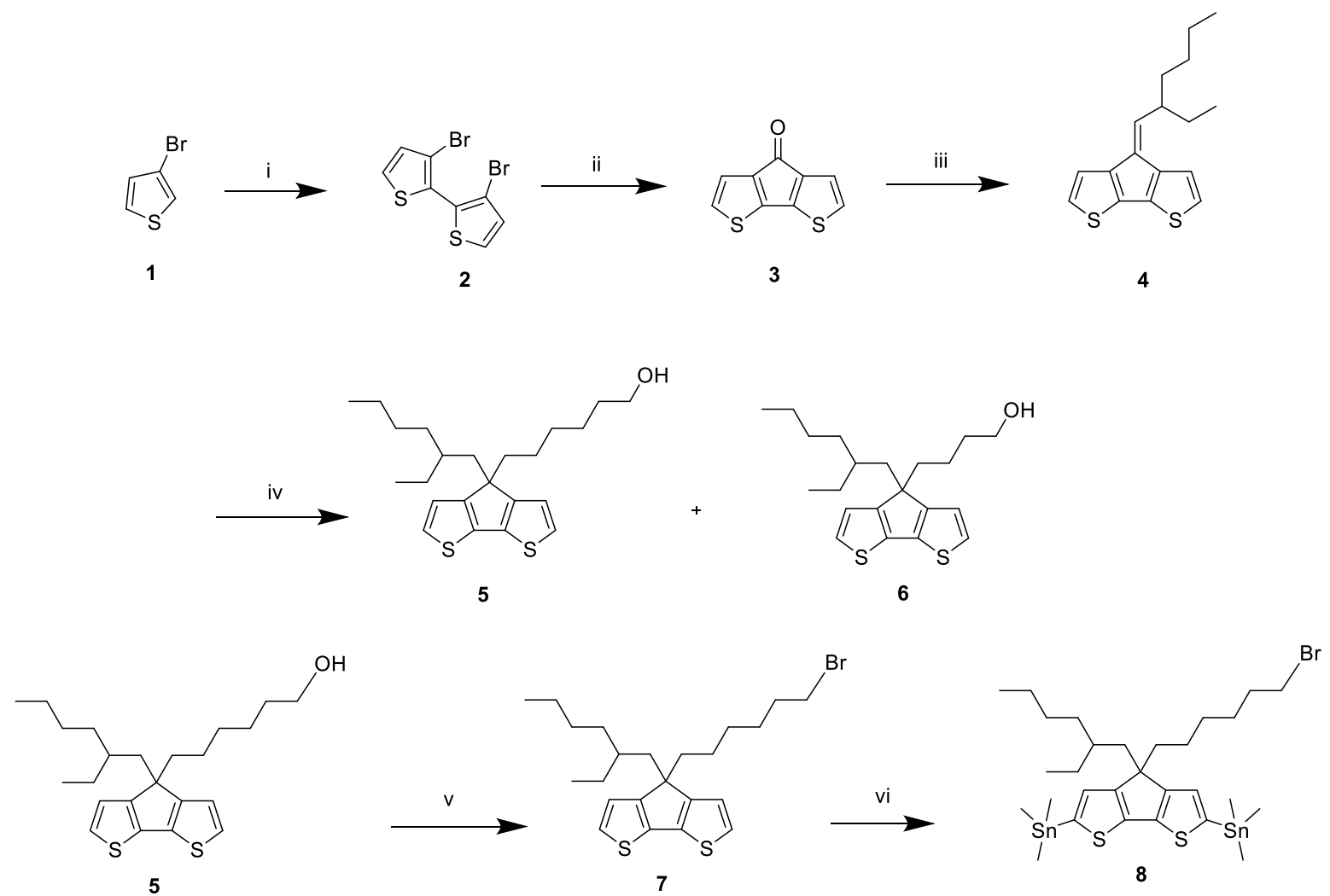

Scheme 1. CPDT monomer synthesis: i) LDA, $\mathrm{CuCl}_{2}, \mathrm{THF}$, overnight at RT (72\%); ii) $n$-BuLi, $\mathrm{ClCONMe}_{2}$, THF, overnight at RT (76\%); iii) 2-ethylhexylphosphonium bromide, $n$-BuLi, THF, 2 h at $-78^{\circ} \mathrm{C}$, overnight at RT (77\%); iv) 1. (6-bromohexyloxy)triisopropylsilane, $\mathrm{LiAlH}_{4}, \mathrm{MTBE}$, overnight at $0{ }^{\circ} \mathrm{C} ; 2$. TBAF $(71 \%$ over two steps); v) $\mathrm{PPh}_{3}, \mathrm{CBr}_{4}, 3 \mathrm{~h}$ at $\mathrm{RT}(94 \%)$; vi) $n$-BuLi, $\mathrm{SnMe}_{3} \mathrm{Cl}, 1.5 \mathrm{~h}$ at $-78^{\circ} \mathrm{C}$ (54\% after prep-SEC). 


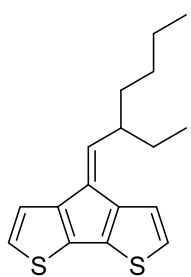

4
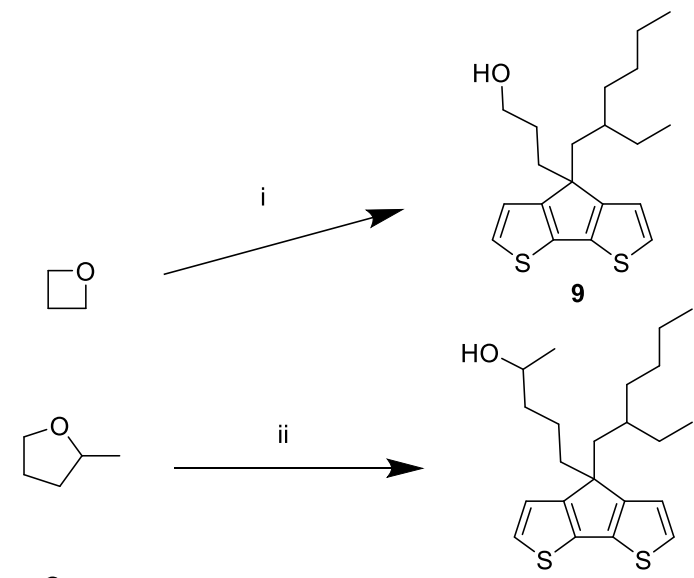

10<smiles>C1CCOCC1</smiles>

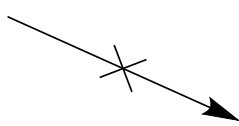

Scheme 2. Reactions of precursor 4 with cyclic ethers: i) MTBE, $\mathrm{LiAlH}_{4}$, overnight at $60{ }^{\circ} \mathrm{C}(65 \%)$; ii) $\mathrm{LiAlH}_{4}$, overnight at $75{ }^{\circ} \mathrm{C}(44 \%)$.

CPDT monomer 8 was then copolymerized with regular $\mathrm{N}$-octyl-2,5-dibromothieno[3,4c] pyrrole-4,6-dione (octyl-TPD 11), prepared through the standard literature procedure, ${ }^{[42]}$ via a Stille cross-coupling polycondensation in the presence of $\mathrm{Pd}_{2} \mathrm{dba}_{3}(2 \mathrm{~mol} \%)$ as a catalyst and $\mathrm{P}(\mathrm{o} \text {-tol })_{3}(8 \mathrm{~mol} \%)$ as a ligand (Scheme 3$)$. The crude polymer was purified using soxhlet extractions with different solvents (acetone, hexanes and chloroform) to remove catalyst residues and low molar mass fractions. A PCPDTTPD polymer with number-average molar mass $\left(M_{n}\right)$ of $13 \mathrm{~kg} \mathrm{~mol}^{-1}$ was obtained (Table 1$)$.
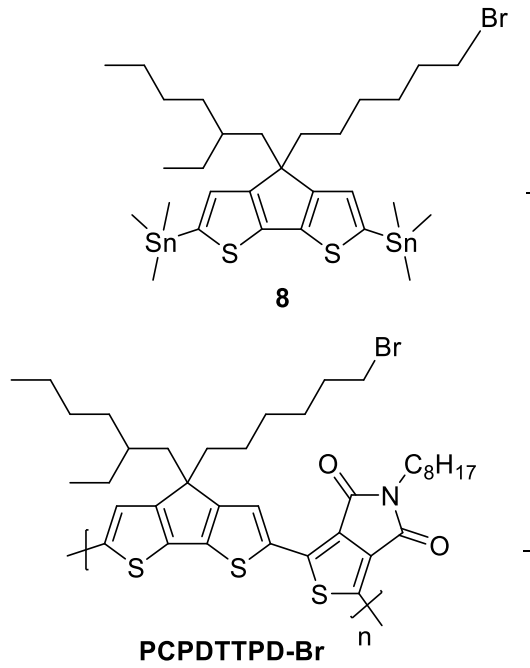

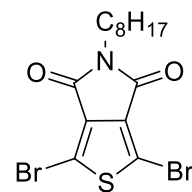

11

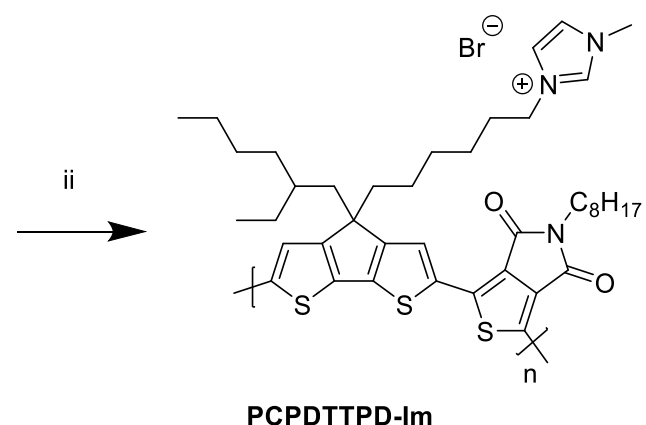

PCPDTTPD-Im

Scheme 3. PCPDTTPD-Im synthesis: i) $\mathrm{Pd}_{2} \mathrm{dba}_{3}, \mathrm{P}(o \text {-tol })_{3}$, toluene/DMF (4/1), reflux overnight (58\%); ii) 1-methylimidazole, $\mathrm{CH}_{3} \mathrm{CN}$, microwave, $4 \mathrm{~h}$ at $100{ }^{\circ} \mathrm{C}(69 \%)$.

Subsequently, the ionic imidazolium moiety was introduced by post-polymerization substitution of the Br-functionalized CPDT side chains (Scheme 3 ). A large excess of the functionalization agent (1-methylimidazole) was added to the polymer in acetonitrile and the 
ionic substitution reaction was activated with microwave irradiation. The polymer was purified again by soxhlet extraction using diethyl ether as a washing solvent to remove the excess of 1-methylimidazole, followed by methanol to collect the ionic polymer. Owing to the ionic imidazole substituent, PCPDTTPD-Im is very soluble in polar solvents (e.g. methanol) and can hence be processed 'orthogonally' on top of the photoactive layer without interface erosion or disruption of the underlying morphology.

The thermal properties of the polymers were investigated by thermogravimetric analysis (TGA) and rapid heat-cool calorimetry (RHC) (Figure S1-S2). RHC was chosen above regular differential scanning calorimetry (DSC) because of its increased sensitivity to thermal transitions resulting from the fast scanning rates and the low sample amounts required. ${ }^{[43]}$ TGA showed that PCPDTTPD-Br is more thermally stable and only starts to degrade at $280^{\circ} \mathrm{C}$, while PCPDTTPD-Im slowly starts to lose weight above $200{ }^{\circ} \mathrm{C}$ (Figure S1). RHC analysis indicated that PCPDTTPD-Br has a broad melting transition around $150-200{ }^{\circ} \mathrm{C}$ (after a preceding cooling at $20 \mathrm{~K} \mathrm{~min}^{-1}$ ), whereas no clear melting transition can be observed for PCPDTTPD-Im (Figure S2). No clear glass transitions could be observed for these polymers.

Prior to device investigation, the optoelectronic material properties (absorption behavior, bandgap and energy levels) were investigated by means of ultraviolet-visible (UV-Vis) absorption spectroscopy and cyclic voltammetry (CV). The UV-Vis absorption spectra were recorded for PCPDTTPD-Br and PCPDTTPD-Im in chloroform and methanol, respectively. No single solvent was found for both materials to simplify comparison. Figure 1 depicts both the solution and solid-state UV-Vis spectra. Peak broadening and a red-shift in the onset of absorption is observed for both polymers when going from solution to thin film, likely due to aggregation in the solid state. The optical bandgap, determined from the onset of absorption in thin film, was estimated at 1.70 and $1.67 \mathrm{eV}$ for PCPDTTPD-Br and PCPDTTPD-Im, respectively. The frontier orbital energy levels for both polymers, obtained from the onset potentials of oxidation and reduction via CV (Figure S3-S4), are listed in Table 1.

Table 1. Molar mass, optical, thermal and electrochemical data for PCPDTTPD-Br and PCPDTTPD-Im.

\begin{tabular}{|c|c|c|c|c|c|c|c|c|c|}
\hline & $\begin{array}{c}M_{\mathrm{n}}{ }^{a} / \mathbf{k g} \\
\mathrm{mol}^{-1}\end{array}$ & $\boldsymbol{\oplus}$ & $\begin{array}{c}\lambda_{\max } \\
\text { film }^{b} / \mathrm{nm}\end{array}$ & $\begin{array}{c}\mathrm{Eg}_{\text {film }}{ }^{c} / \\
\mathrm{eV}\end{array}$ & $\begin{array}{c}E_{o x}{ }^{d} / \\
e V\end{array}$ & $\begin{array}{c}E_{\text {red }}{ }^{d} / \\
\text { eV }\end{array}$ & $\begin{array}{c}\mathrm{Eg}_{\mathrm{cv}}{ }^{2} / \\
\mathrm{eV}\end{array}$ & $\begin{array}{c}\text { Еномо }^{f} / \\
\mathrm{eV}\end{array}$ & $\begin{array}{c}\text { ELumo }^{f} / \\
\text { eV }\end{array}$ \\
\hline PCPDTTPD-Br & 13 & 1.5 & 690 & 1.70 & 0.46 & -1.50 & 1.96 & -5.42 & -3.46 \\
\hline PCPDTTPD-Im & - & - & 622 & 1.67 & 0.35 & -1.44 & 1.79 & -5.31 & -3.52 \\
\hline
\end{tabular}

${ }^{a}$ Measured by SEC at $40{ }^{\circ} \mathrm{C}$ in THF. ${ }^{b}$ Films were prepared by drop-casting a solution of the polymer onto a quartz disc. ${ }^{c}$ Optical bandgap, determined by the onset of the solid-state UV-Vis spectrum. ${ }^{d}$ Onset potentials vs. $\mathrm{Fc} / \mathrm{Fc}^{+}$. ${ }^{e}$ Electrochemical bandgap. ${ }^{f}$ Determined from the onset of oxidation/reduction in cyclic voltammetry. 

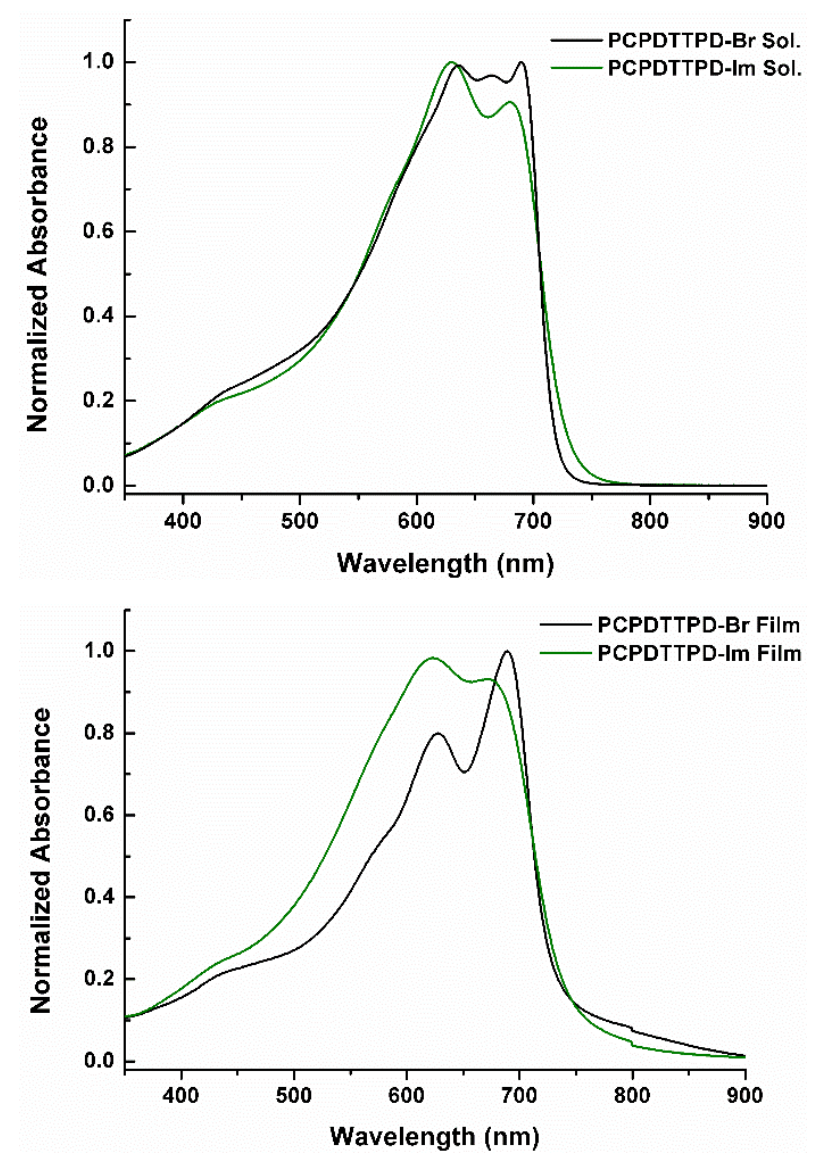

Figure 1. Normalized UV-Vis absorption spectra for PCPDTTPD-Br and PCPDTTPD-Im in solution (top) and thin film (bottom).

\section{OPV device fabrication and analysis}

To investigate the photovoltaic effectiveness of the novel CPE material, $\mathrm{BHJ}$ organic solar cells with a standard configuration glass/ITO/PEDOT:PSS/PBDTTPD:[70]PCBM/CPE (or Ca)/Al were fabricated (Figure 2, bottom). For the photoactive layer, PBDTTPD was chosen because of its relatively high efficiency, comparatively low synthetic complexity and the ease by which this polymer can be synthesized on a large scale using continuous flow chemistry. ${ }^{[44]}$ The blend solution of PBDTTPD:[70]PCBM (1:1.5) was spin-coated on top of PEDOT:PSS from chlorobenzene using 5\% 1-chloronapthalene (CN) as the co-solvent. ${ }^{[44]}$ PCPDTTPD-Im was then spin-coated on top of the active layer from methanol using various concentrations $(0.25$, $0.5,1,2$ and $4 \mathrm{mg} \mathrm{mL}^{-1}$ ). As shown in Table 2, the photovoltaic performance significantly increased across the entire CPE concentration range, mainly due to the increase in $J_{\text {sc }}$ and a small gain in FF. The best results were obtained when employing a CPE concentration of $1 \mathrm{mg}$ $\mathrm{mL}^{-1}$, granting an average PCE increase from 6.9 to $7.5 \%$ (Figure 2, top), with a top PCE of $7.8 \%$. A control device with pure methanol spin-coated on top of the photoactive layer also provided some efficiency increase $(\sim 5 \%),{ }^{[21]}$ in accordance with previous findings, ${ }^{[23,29]}$ but the obtained values were still (significantly) lower than those observed upon incorporation of the CPE interlayer. External quantum efficiency (EQE) measurements (Figure 2, middle) revealed an increased photocurrent in the 300-550 $\mathrm{nm}$ range for the best CPE bearing device, surpassing $65 \%$ at $\sim 450 \mathrm{~nm} .{ }^{[21]}$ The integrated current densities from the EQE (JEQE $)$ were found to be 
10.43 and $11.05 \mathrm{~mA} \mathrm{~cm}^{-2}$ for the reference device and the CPE device, respectively, correlating well with the measured $J_{\text {sc }}$ 's.
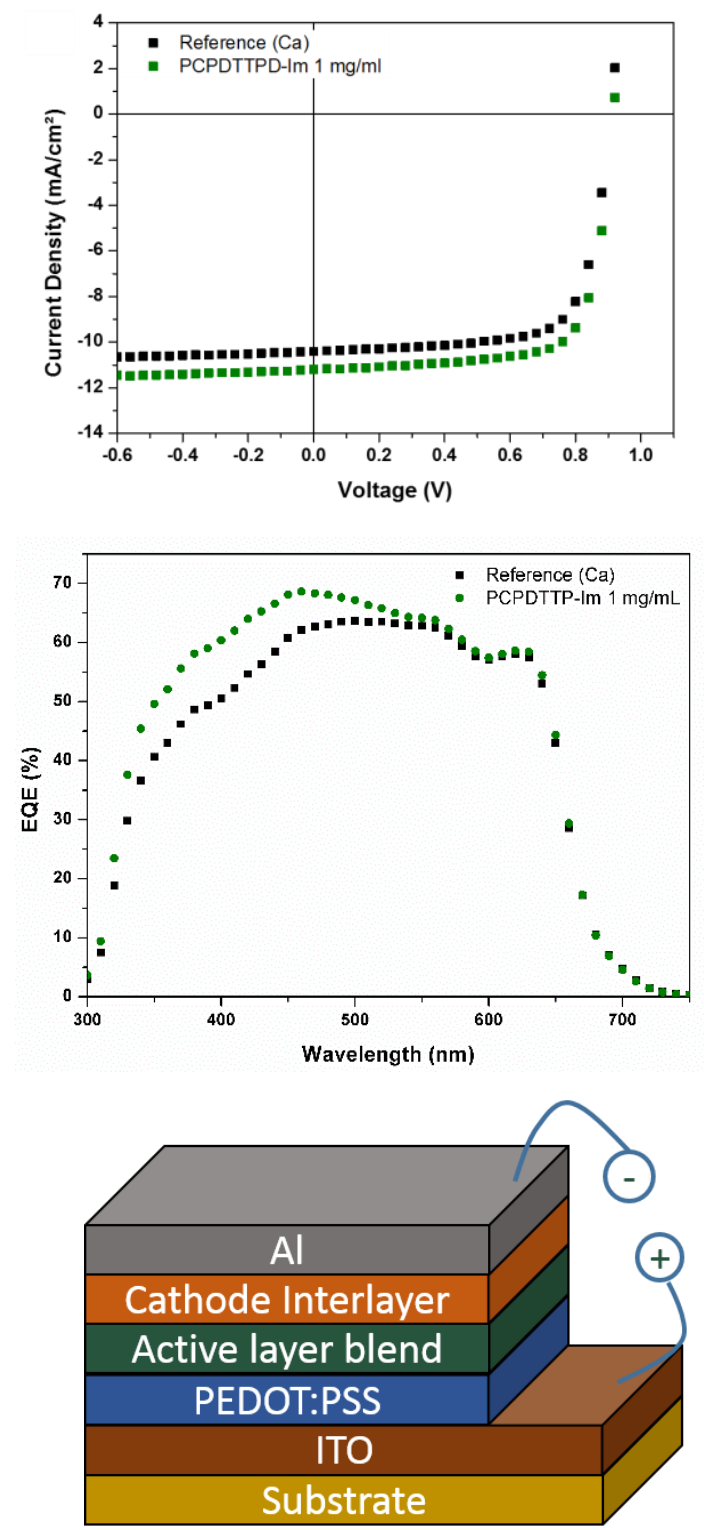

Figure 2. J-V curves (top) and EQE spectra (middle) of average performing BHJ solar cell devices containing either Ca or the PCPDTTPD-Im CPE interlayer (spin-coated from a $1 \mathrm{mg} \mathrm{mL}^{-1}$ solution in methanol). The employed solar cell stack is depicted as well (bottom).

Atomic force microscopy (AFM) measurements were performed on the polymer solar cells treated with varying CPE concentrations to investigate possible trends (Figure 3 ). The CPE material seems uniformly distributed on top of the active layer, without formation of large clusters (in contrast to previous work ${ }^{[21,23]}$ ). However, no real fluctuations in topography could be observed upon changing the CPE concentration. Only when employing a solution of $4 \mathrm{mg}$ $\mathrm{mL}^{-1}$, a small enlargement of the domains could be identified. 
Table 2. Photovoltaic parameters for PBDTTPD:[70]PCBM organic solar cells employing either Ca or the PCPDTTPD-Im interlayer.

\begin{tabular}{cccccc}
\hline $\begin{array}{c}\text { CPE concentration / } \\
\mathbf{m g ~ m L}^{-1}\end{array}$ & $\begin{array}{c}\boldsymbol{V}_{\mathrm{oc}} / \\
\mathbf{V}\end{array}$ & $\begin{array}{c}J_{\mathrm{sc}} / \mathbf{m A} \\
\mathbf{c m}^{-2}\end{array}$ & $\mathbf{F F}$ & $\begin{array}{c}\text { Average PCE } \\
/ \%\end{array}$ & $\begin{array}{c}\text { Best PCE } \\
/ \%\end{array}$ \\
\hline Reference (Ca) & 0.92 & 10.53 & 0.71 & 6.89 & 6.95 \\
0.25 & 0.92 & 10.87 & 0.74 & 7.39 & 7.54 \\
0.5 & 0.92 & 11.08 & 0.73 & 7.49 & 7.80 \\
1 & 0.92 & 11.18 & 0.73 & 7.54 & 7.83 \\
2 & 0.92 & 11.07 & 0.73 & 7.44 & 7.79 \\
4 & 0.92 & 10.37 & 0.72 & 6.91 & 7.22 \\
\hline
\end{tabular}

${ }^{a}$ Average efficiencies over at least 4 devices.
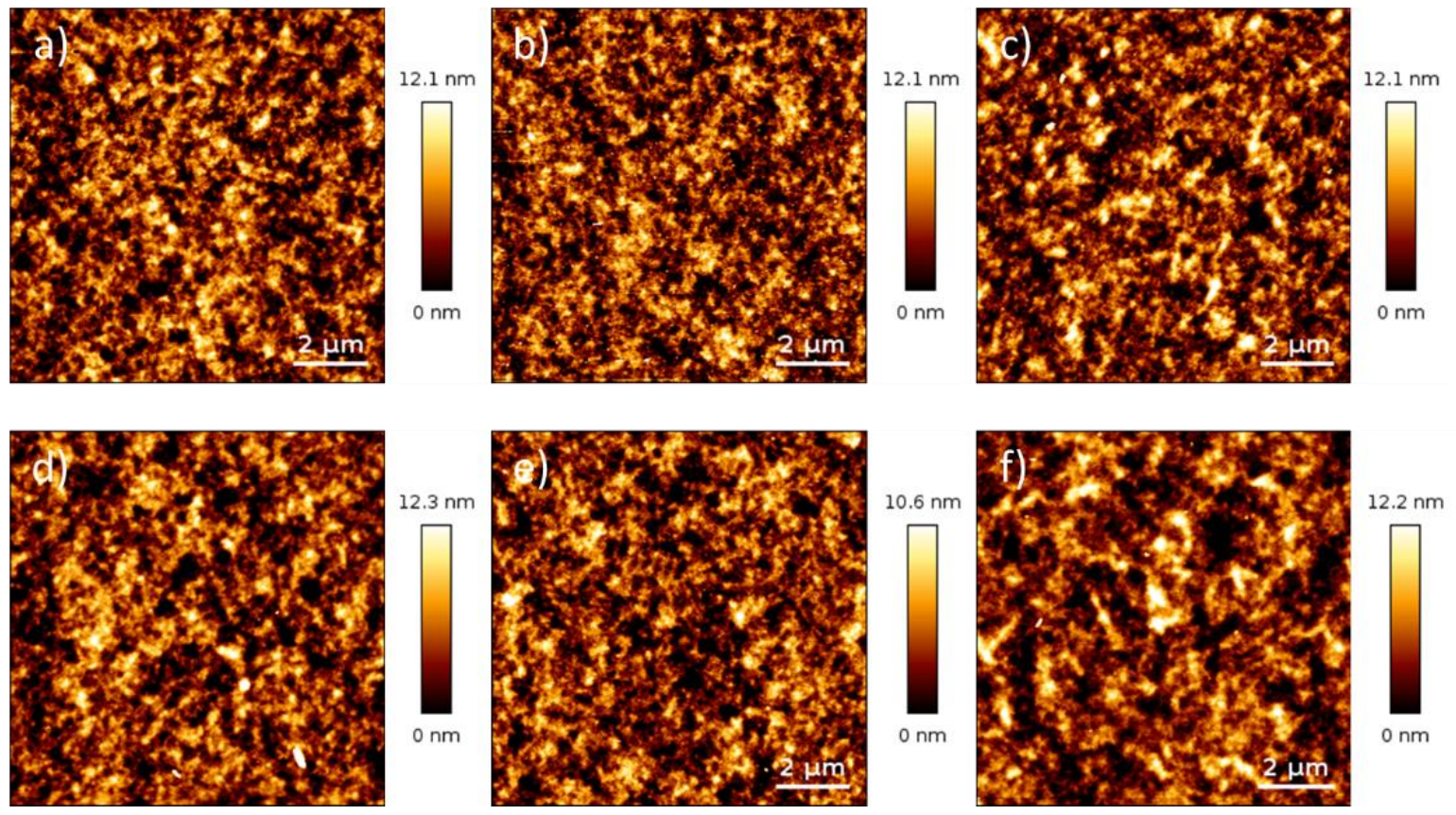

Figure 3. AFM images $(10 \times 10 \mu \mathrm{m})$ of PBDTTPD:[70]PCBM organic solar cells employing a) no CPE, $b$ ) 0.25 , c) 0.5 , d) 1 , e) 2 and f) $4 \mathrm{mg} \mathrm{mL}^{-1}$ of PCPDTTPD-Im methanolic solution spin-coated on top of the active layer.

\section{Conclusions}

We have synthesized a PCPDTTPD-based narrow bandgap conjugated polyelectrolyte bearing imidazolium-type ionic side chains as a cathode interlayer for organic solar cells. A significant 
improvement in power conversion efficiency was demonstrated when this interlayer material was applied in combination with a PBDTTPD:[70]PCBM photoactive layer. An efficiency increase of $13 \%$ was achieved for the best performing device, especially due to the improved short-circuit current. In contrast to (some) other reported CPEs, ${ }^{[21,23]}$ the cathode interlayer seems to cover the active layer in a uniform way. Further efforts are currently done to translate these results to different (organic or hybrid organic-inorganic) active layer blends and to test the CPE as a donor-type active layer material in combination with a compatible electron acceptor.

\section{Acknowledgements}

This work was supported by the Research Program of the Research Foundation - Flanders (FWO) (projects G.0415.14N, G.0B67.15N, M.ERA-NET project RADESOL and postdoctoral fellowship J.K.). J.B. acknowledges the former Agency for Innovation by Science and Technology in Flanders (IWT; now FWO-SB) for his PhD grant. The authors are also grateful to $\mathrm{H}$. Penxten for the CV measurements. Hasselt University and IMO-IMOMEC are partners in the Solliance network, the strategic alliance for research and development in the field of thin-film $\mathrm{PV}$ energy in the Eindhoven-Leuven-Aachen region.

\section{Supplementary material}

${ }^{1} \mathrm{H}$ and ${ }^{13} \mathrm{C}$ NMR spectra, thermal analysis and cyclic voltammetry figures can be found in the supplementary material.

\section{Experimental section}

\section{Materials and methods}

All reagents and chemicals were obtained from commercial sources and used without further purification. Solvents were dried by a solvent purification system (MBraun, MB-SPS-800) equipped with alumina columns. Preparative (recycling) size exclusion chromatography (prepSEC) was performed on a JAI LC-9110 NEXT system equipped with JAIGEL $1 H$ and $2 H$ columns (eluent $\mathrm{CHCl}_{3}$, flow rate $\left.3.5 \mathrm{~mL} \mathrm{~min}{ }^{-1}\right)$. NMR chemical shifts $(\delta$, in ppm) were determined relative to the residual $\mathrm{CHCl}_{3}$ (7.26 ppm), $\mathrm{CH}_{2} \mathrm{Cl}_{2}$ (5.32 ppm) or $\mathrm{CH}_{3} \mathrm{OH}$ (3.31 ppm) absorption or the ${ }^{13} \mathrm{C}$ resonance shift of $\mathrm{CDCl}_{3}$ (77.16 ppm) or $\mathrm{CD}_{2} \mathrm{Cl}_{2}(54.00 \mathrm{ppm})$. High resolution ESI-MS was performed using a LTQ Orbitrap Velos Pro mass spectrometer equipped with an atmospheric pressure ionization source operating in the nebulizer assisted electrospray mode. The instrument was calibrated in the $\mathrm{m} / \mathrm{z}$ range $220-2000$ using a standard solution containing caffeine, MRFA and Ultramark 1621. UV-Vis absorption spectroscopy measurements were performed on a VARIAN Cary 5000 UV-Vis spectrophotometer at a scan rate of $600 \mathrm{~nm} \mathrm{~min}{ }^{-1}$. The films for the UV-Vis absorption measurements were prepared by drop casting a solution of the respective polymer in chloroform or methanol on a quartz substrate. The solid-state UV-Vis absorption spectra were used to estimate the optical bandgaps (from the wavelength at the intersection of the tangent line drawn at the low energy side of the absorption spectrum with the baseline: $E_{\mathrm{g}}(\mathrm{eV})=1240 /($ wavelength in $\mathrm{nm}$ )). Analysis of the molar mass and molar mass distribution of PCPDTTPD-Br was performed on a Tosoh EcoSEC System, comprising of 
an autosampler, a PSS guard column SDV $(50 \times 7.5 \mathrm{~mm})$, followed by three PSS SDV analytical linear XL columns $(5 \mu \mathrm{m}, 300 \times 7.5 \mathrm{~mm})$ and a UV-detector using THF as the eluent at $40{ }^{\circ} \mathrm{C}$ with a flow rate of $1.0 \mathrm{~mL} \mathrm{~min}{ }^{-1}$. The SEC system was calibrated using linear narrow polystyrene standards ranging from 474 to $7.5 \times 10^{6} \mathrm{~g} \mathrm{~mol}^{-1}\left(\mathrm{~K}=14.1 \times 10^{-5} \mathrm{dL} \mathrm{g}^{-1}\right.$ and $\left.\alpha=0.70\right)$. Electrochemical measurements (cyclic voltammetry) were performed with an Eco Chemie Autolab PGSTAT 30 potentiostat/galvanostat using a three-electrode microcell with a platinum working electrode, a platinum counter electrode and a $\mathrm{Ag} / \mathrm{AgNO}_{3}$ reference electrode (silver wire dipped in a solution of $0.01 \mathrm{M} \mathrm{AgNO}_{3}$ and $0.1 \mathrm{M} \mathrm{NBu}_{4} \mathrm{PF}_{6}$ in anhydrous acetonitrile). The reference electrode was calibrated against ferrocene/ferrocenium as an external standard. The PCPDTTPD-Br sample was prepared by dip coating the platinum working electrode in a polymer solution in chloroform (the same solution as used for the solidstate UV-Vis measurements), while PCPDTTPD-Im was measured in MeCN solution. The CV measurements were done with $0.1 \mathrm{M} \mathrm{NBu}_{4} \mathrm{PF}_{6}$ in anhydrous acetonitrile as electrolyte solution. To prevent air from entering the system, the experiments were carried out under a curtain of argon. Cyclic voltammograms were recorded at a scan rate of $100 \mathrm{mV} \mathrm{s}^{-1}$. For the conversion of $\mathrm{V}$ to $\mathrm{eV}$, the onset potentials of the first oxidation/reduction peaks were used and referenced to ferrocene/ferrocenium, which has an ionization potential of $-4.98 \mathrm{eV} v \mathrm{v}$. vacuum. This correction factor is based on a value of $0.31 \mathrm{eV}$ for $\mathrm{Fc} / \mathrm{Fc}^{+} \mathrm{vs}$. SCE ${ }^{[45]}$ and a value of $4.68 \mathrm{eV}$ for SCE vs. vacuum ${ }^{[46]}$ : $E_{\text {HOMO/LUMO }}(\mathrm{eV})=-4.98-E_{\text {onset ox } / \mathrm{red}}{ }^{\mathrm{Ag} / \mathrm{AgNO}}(\mathrm{V})+E_{\text {onset Fc/Fc+ }}$ $\mathrm{Ag} / \mathrm{AgNO}(\mathrm{V})$. The accuracy of measuring redox potentials by $\mathrm{CV}$ is about 0.01-0.02 $\mathrm{V}$. Reproducibility can be less because the potentials depend on concentration and temperature. Rapid heat-cool calorimetry experiments were performed on a prototype RHC of TA Instruments, equipped with liquid nitrogen cooling and specifically designed for operation at high scanning rates. RHC measurements were performed at $500 \mathrm{~K} \mathrm{~min}^{-1}$ (after cooling at $20 \mathrm{~K}$ $\mathrm{min}^{-1}$ ) using aluminum crucibles filled with samples of $200-250 \mu \mathrm{g}$, using helium (10 mL min $\left.{ }^{1}\right)$ as a purge gas. TGA experiments were performed at $20 \mathrm{~K} \mathrm{~min}^{-1}$ in platinum crucibles on a TA Instruments Q5000 TGA using nitrogen (50 $\left.\mathrm{mL} \mathrm{min}^{-1}\right)$ as purge gas.

\section{Solar cell fabrication and characterization}

Before device processing, the indium tin oxide (ITO, Kintec, $100 \mathrm{~nm}, 20 \mathrm{Ohm} \mathrm{sq}^{-1}$ ) containing substrates were thoroughly cleaned through sonication using soap, demineralized water, acetone, isopropyl alcohol and a UV/O ${ }_{3}$ treatment. Subsequently, a layer of PEDOT:PSS (poly(3,4-ethylenedioxythiophene):poly(styrenesulfonic acid); Heraeus Clevios Al 4083) was spin-coated on top of the pre-patterned ITO substrates. Further processing was performed under $\mathrm{N}_{2}$ atmosphere in a glove box, starting with an annealing step at $130{ }^{\circ} \mathrm{C}$ for $15 \mathrm{~min}$ to remove any residual water. The PBDTTPD:[70]PCBM (Solenne) active layers were spin-coated targeting thicknesses of $\sim 100-120 \mathrm{~nm}$, as confirmed by profilometry (DEKTAK). The blend solutions providing highest efficiencies contained a 1:1.5 (PBDTTPD:[70]PCBM) ratio, with polymer concentrations of $20 \mathrm{mg} \mathrm{mL}^{-1}$, using chlorobenzene as the processing solvent and $5 \%$ CN as co-solvent (see Table 2). ${ }^{[4]}$ On top of the active layer, PCPDTTPD-Im was spin-coated from methanol with various concentrations or Ca was evaporated in vacuo with a thickness of 
$30 \mathrm{~nm}$ (for the reference device). The devices were finished off with Al as the top electrode, with a thickness of $80 \mathrm{~nm}$. The active area $\left(3.08 \mathrm{~mm}^{2}\right)$ was defined using a mask. The output parameters of the polymer solar cells were measured using a Newport class A solar simulator (model 91195A), calibrated with a silicon solar cell to give a 1 sun AM 1.5G spectrum. EQE measurements were performed with a Newport Apex illuminator (100 W xenon lamp, 6257) as light source, a Newport Cornerstone 130 monochromator and a Stanford SR830 lock-in amplifier for the current measurements. Calibration was done with a certificated Si FDS-100 photodiode. AFM experiments were performed with a JPK NanoWizard 3 AFM (JPK Instruments AG, Berlin, Germany) using AC mode in air. Silicon ACTA-50 tips from AppNano with cantilever length $\sim 125 \mu \mathrm{m}$, spring constant $\sim 40 \mathrm{~N} / \mathrm{m}$ and resonance frequency $\sim 300 \mathrm{kHz}$ were used. The scan angle, set point height, gain values and scan rate were adjusted according to the calibration of the AFM tip.

\section{Material synthesis and characterization}

3,3'-Dibromo-2,2'-bithiophene (2). ${ }^{[38]}$ 3-Bromothiophene (32.6 g, $200 \mathrm{mmol}$ ) was dissolved in dry THF and LDA (100 mL, $200 \mathrm{mmol}$ ) was added dropwise at $-78^{\circ} \mathrm{C}$ under inert atmosphere. The solution was stirred for $1.5 \mathrm{~h}$ at $-78^{\circ} \mathrm{C}$. $\mathrm{CuCl}_{2}(29.6 \mathrm{~g}, 220 \mathrm{mmol})$ was then added and the reaction mixture was stirred overnight at room temperature. The reaction was quenched with a $1 \mathrm{M} \mathrm{HCl}$ solution, dichloromethane was added and the organic phase was washed with water $(2 \times)$, dried over anhydrous $\mathrm{MgSO}_{4}$ and filtered. The solvent was removed under reduced pressure and the crude product was purified by flash chromatography (silica, $n$-hexane: dichloromethane, 50:50) and Kügelröhr distillation $\left(2 * 10^{-2}\right.$ mbar, $\left.110{ }^{\circ} \mathrm{C}\right)$. After recrystallization from ethanol, 3,3'-dibromo-2,2'-bithiophene was obtained as white crystals (22.0 g, 72\%). ${ }^{1} \mathrm{H}$ NMR (400 MHz, $\left.\mathrm{CDCl}_{3}\right), \delta(\mathrm{ppm}): 7.41$ (d, J=5.4 Hz, $\left.2 \mathrm{H}\right), 7.08(\mathrm{~d}, J=5.4 \mathrm{~Hz}$, $2 \mathrm{H})$.

4H-Cyclopenta[2,1-b:3,4-b']dithiophen-4-one (3). ${ }^{[39]}$ 3,3'-Dibromo-2,2'-bithiophene (10.0 g, $30.8 \mathrm{mmol}$ ) was dissolved in dry diethyl ether and the solution was cooled to $-78{ }^{\circ} \mathrm{C}$ under inert atmosphere. $n$-BuLi $(27.2 \mathrm{~mL}, 67.9 \mathrm{mmol})$ was added dropwise and after stirring the solution for $1 \mathrm{~h}$ at $-78{ }^{\circ} \mathrm{C}$, dimethylcarbamoyl chloride $(3.1 \mathrm{~mL}, 33.9 \mathrm{mmol}$ ) was added dropwise. The solution was then stirred overnight at room temperature. Diethyl ether was added and the organic phase was washed with water $(2 \times)$, dried over anhydrous $\mathrm{MgSO}_{4}$ and filtered. The solvent was removed under reduced pressure. To obtain pure product, recrystallization from ethanol was performed to afford 4H-cyclopenta[2,1-b:3,4-b']dithiophen4-one as red crystals (4.5 g, 76\%). ${ }^{1} \mathrm{H}$ NMR (400 MHz, CDCl 3 ), $\delta(p p m): 7.04(\mathrm{~d}, J=4.8 \mathrm{~Hz}, 2 \mathrm{H})$, $7.00(\mathrm{~d}, J=4.9 \mathrm{~Hz}, 2 \mathrm{H})$.

\section{4-(2-Ethylhexylidene)-4H-cyclopenta[2,1-b:3,4-b']dithiophene (4). ${ }^{[40]}$}

Ethylhexyl)triphenylphosphonium bromide (12.26 g, $32.7 \mathrm{mmol}$ ) was dissolved in dry THF (30 $\mathrm{mL}$ ) and the solution was cooled to $-78{ }^{\circ} \mathrm{C}$ under inert atmosphere. $n$-BuLi (10.8 mL, 11.7 $\mathrm{mmol}$ ) was added dropwise and the solution was allowed to stir for $30 \mathrm{~min}$ at this temperature. 4H-Cyclopenta[2,1-b:3,4- $b^{\prime}$ ] dithiophen-4-one (4.00 g, $20.9 \mathrm{mmol}$ ) was dissolved in dry diethyl ether $(30 \mathrm{~mL})$ and added to the previously prepared solution. The reaction 
mixture was stirred overnight at room temperature. Diethyl ether was added and the organic phase was washed with water (2x), dried over anhydrous $\mathrm{MgSO}_{4}$ and filtered. The crude product was purified by column chromatography (silica, eluent petroleum ether) to yield 4-(2ethylhexylidene)-4H-cyclopenta[2,1-b:3,4- $\left.b^{\prime}\right]$ dithiophene as a yellow solid (4.6 g, 77\%). ${ }^{1} \mathrm{H}$ NMR (400 MHz, CDCl $), \delta(p p m): 7.28(\mathrm{~d}, J=5.0 \mathrm{~Hz}, 2 \mathrm{H}), 7.15(\mathrm{~d}, J=5.0 \mathrm{~Hz}, 2 \mathrm{H}), 6.16(\mathrm{~d}, J=$ $10.5 \mathrm{~Hz}, 1 \mathrm{H}), 2.94-2.83(\mathrm{~m}, 1 \mathrm{H}), 1.72-1.58(\mathrm{~m}, 2 \mathrm{H}), 1.50-1.39(\mathrm{~m}, 2 \mathrm{H}), 1.33-1.25(\mathrm{~m}, 4 \mathrm{H}), 0.92$ $(\mathrm{t}, J=7.4 \mathrm{~Hz}, 3 \mathrm{H}), 0.85(\mathrm{t}, J=7.0 \mathrm{~Hz}, 3 \mathrm{H})$.

6-[4-(2-Ethylhexyl)-4H-cyclopenta[2,1-b:3,4-b']dithiophen-4-yl]hexan-1-ol (5). Prepared according to a modified literature procedure. ${ }^{[0]}$ A solution of 4-(2-ethylhexylidene)- $4 \mathrm{H}$ cyclopenta[2,1-b:3,4- $b^{\prime}$ ]dithiophene $\quad(1.01 \quad \mathrm{~g}, \quad 3.47 \quad \mathrm{mmol})$ and (6broomhexyloxy)triisopropylsilane $(1.17 \mathrm{~g}, 3.47 \mathrm{mmol})$ in dry methyl-tert-butyl ether (MTBE, $25 \mathrm{~mL}$ ) was added to a suspension of $\mathrm{LiAlH}_{4}(0.292 \mathrm{~g}, 3.47 \mathrm{mmol})$ in dry MTBE $(10 \mathrm{~mL})$ at $60{ }^{\circ} \mathrm{C}$ under inert atmosphere. The reaction was stirred overnight at $60^{\circ} \mathrm{C} .1 \mathrm{M} \mathrm{HCl}$ solution and diethyl ether $(50 \mathrm{~mL})$ were carefully added and the organic phase was washed with $\mathrm{NaHCO}_{3}$ and water (2x), dried over anhydrous $\mathrm{MgSO}_{4}$ and filtered. After removing the solvent under reduced pressure, the resulting product was dissolved in THF $(15 \mathrm{~mL})$ and TBAF $(1.13 \mathrm{~g}, 4.33$ $\mathrm{mmol}$ ) was added under inert atmosphere. The solution was stirred overnight at room temperature, followed by the addition of diethyl ether and water. The organic phase was washed with with water (2x), dried over anhydrous $\mathrm{MgSO}_{4}$ and filtered. The solvent was removed under reduced pressure and the crude product was purified by column chromatography (silica, eluent petroleum ether:diethyl ether, 70:30). 6-[4-(2-Ethylhexyl)-4Hcyclopenta[2,1-b:3,4- $\left.b^{\prime}\right]$ dithiophen-4-yl]hexan-1-ol was obtained as a yellow oil (0.966 g, 71\%). ${ }^{1} \mathrm{H}$ NMR $\left(400 \mathrm{MHz}, \mathrm{CDCl}_{3}\right), \delta(\mathrm{ppm}): 7.12(\mathrm{~d}, J=4.9 \mathrm{~Hz}, 2 \mathrm{H}), 6.90(2 \mathrm{~d}, J=4.9 \mathrm{~Hz}, 2 \mathrm{H}), 3.54(\mathrm{t}, J$ $=6.6 \mathrm{~Hz}, 2 \mathrm{H}), 1.93-1.75(\mathrm{~m}, 4 \mathrm{H}), 1.46-1.37(\mathrm{~m}, 3 \mathrm{H}), 1.25-1.08(\mathrm{~m}, 5 \mathrm{H}), 1.02-0.81(\mathrm{~m}, 10 \mathrm{H})$, $0.74(t, J=7.1 \mathrm{~Hz}, 3 \mathrm{H}), 0.66-0.50(\mathrm{~m}, 4 \mathrm{H})$.

During this reaction, 4-[4-(2-ethylhexyl)-4H-cyclopenta[2,1-b:3,4-b']dithiophen-4-yl]butan-1ol (6) was also obtained due to a reaction with THF $(0.13 \mathrm{~g}, 10 \%) .{ }^{1} \mathrm{H} \mathrm{NMR}\left(400 \mathrm{MHz}, \mathrm{CDCl}_{3}\right), \delta$ (ppm): $7.12(\mathrm{~d}, J=4.9 \mathrm{~Hz}, 2 \mathrm{H}), 6.91(2 \mathrm{~d}, J=4.9 \mathrm{~Hz}, 2 \mathrm{H}), 3.45(\mathrm{t}, J=6.6 \mathrm{~Hz}, 2 \mathrm{H}), 1.93-1.79(\mathrm{~m}$, $4 \mathrm{H}), 1.35-1.25(\mathrm{~m}, 3 \mathrm{H}), 0.99-0.85(\mathrm{~m}, 10 \mathrm{H}), 0.74(\mathrm{t}, J=7.0 \mathrm{~Hz}, 3 \mathrm{H}), 0.66-0.55(\mathrm{~m}, 4 \mathrm{H}) .{ }^{13} \mathrm{C} N M R$ $\left(100 \mathrm{MHz}, \mathrm{CDCl}_{3}\right), \delta$ (ppm): 157.51, 157.47, 136.7, 124.4, 121.84, 121.81, 62.6, 53.1, 41.7, 39.3, $35.2,34.0,33.0,28.5,27.2,22.7,20.1,14.1,10.6$. HRMS (ESI): calcd. for $\mathrm{C}_{21} \mathrm{H}_{30} \mathrm{OS}_{2}[\mathrm{M}+\mathrm{H}]^{+}$: 363.1817, measured: 363.1764 .

4-(6-Bromohexyl)-4-(2-ethylhexyl)-4H-cyclopenta[2,1-b:3,4-b']dithiophene (7). Prepared according to a literature procedure. ${ }^{[40]} \mathrm{A}$ solution of triphenylphosphine $(0.713 \mathrm{~g}, 2.72 \mathrm{mmol})$ in dry $\mathrm{CH}_{2} \mathrm{Cl}_{2}(5 \mathrm{~mL})$ was added drop wise to a solution of 6-[4-(2-ethylhexyl)-4Hcyclopenta[2,1-b:3,4- $\left.b^{\prime}\right]$ dithiophen-4-yl]hexan-1-ol $(0.760 \quad \mathrm{~g}, \quad 1.94 \mathrm{mmol})$ and tetrabromomethane $(0.837 \mathrm{~g}, 2.52 \mathrm{mmol})$ in dry $\mathrm{CH}_{2} \mathrm{Cl}_{2}(10 \mathrm{~mL})$ at $0{ }^{\circ} \mathrm{C}$. After stirring the solution for $3 \mathrm{~h}$ at room temperature, diethyl ether and water were added and the organic phase was washed with $\mathrm{NaHCO}_{3}(2 \times)$ and water $(2 \times)$, dried over anhydrous $\mathrm{MgSO}_{4}$ and filtered. The solvent was removed under reduced pressure and the crude product was purified by column chromatography (silica, eluent petroleum ether) to yield 4-(6-bromohexyl)-4-(2ethylhexyl)-4H-cyclopenta[2,1-b:3,4-b']dithiophene as a yellow oil (0.83 g, 94\%). ${ }^{1} \mathrm{H}$ NMR (300 
$\left.\mathrm{MHz}, \mathrm{CDCl}_{3}\right), \delta(\mathrm{ppm}): 7.13(\mathrm{~d}, J=4.9 \mathrm{~Hz}, 2 \mathrm{H}), 6.92(2 \mathrm{~d}, J=4.9 \mathrm{~Hz}, 2 \mathrm{H}), 3.32(\mathrm{t}, J=6.8 \mathrm{~Hz}, 2 \mathrm{H})$, $1.91-1.67(\mathrm{~m}, 6 \mathrm{H}), 1.30-1.21(\mathrm{~m}, 2 \mathrm{H}), 1.17-1.07(\mathrm{~m}, 2 \mathrm{H}), 1.01-0.82(\mathrm{~m}, 10 \mathrm{H}), 0.75(\mathrm{t}, J=6.9$ $\mathrm{Hz}, 3 \mathrm{H}), 0.66-0.55(\mathrm{~m}, 4 \mathrm{H})$.

\section{[4-(6-Bromohexyl)-4-(2-ethylhexyl)-4H-cyclopenta[2,1-b:3,4-b']dithiophene-2,6-}

diyl]bis(trimethylstannane) (8). 4-(6-Bromohexyl)-4-(2-ethylhexyl)-4H-cyclopenta[2,1-b:3,4$b^{\prime}$ ]dithiophene $(0.200 \mathrm{~g}, 0.327 \mathrm{mmol})$ was dissolved in dry THF $(2.5 \mathrm{~mL})$ and the solution was cooled down to $-78{ }^{\circ} \mathrm{C}$ under inert atmosphere. $n$-BuLi $(0.26 \mathrm{~mL}, 0.661 \mathrm{mmol})$ was added dropwise and the mixture was stirred for $30 \mathrm{~min}$ at $-78{ }^{\circ} \mathrm{C}$. Trimethyltin chloride $(0.72 \mathrm{~mL}$, $0.720 \mathrm{mmol}$ ) was added and the reaction mixture was allowed to gently warm to room temperature. After $1.5 \mathrm{~h}$, diethyl ether was added and the organic phase was washed with water (2x), dried over anhydrous $\mathrm{MgSO}_{4}$ and filtered. Further purification of the monomer was done by recycling prep-SEC $\left(\mathrm{CHCl}_{3}\right)$ to yield [4-(6-bromohexyl)-4-(2-ethylhexyl)-4Hcyclopenta[2,1-b:3,4-b']dithiophene-2,6-diyl]bis(trimethylstannane) as a yellow oil (0.137 $\mathrm{g}$, 54\%). ${ }^{1} \mathrm{H}$ NMR $\left(300 \mathrm{MHz}, \mathrm{CD}_{2} \mathrm{Cl}_{2}\right): 6.99(2 \mathrm{~s}, 2 \mathrm{H}), 3.34(\mathrm{t}, J=6.9 \mathrm{~Hz}, 2 \mathrm{H}), 1.91-1.68(\mathrm{~m}, 6 \mathrm{H}), 1.33-$ $1.24(\mathrm{~m}, 2 \mathrm{H}), 1.20-1.10(\mathrm{~m}, 2 \mathrm{H}), 1.02-0.83(\mathrm{~m}, 10 \mathrm{H}), 0.74(\mathrm{t}, J=6.9 \mathrm{~Hz}, 3 \mathrm{H}), 0.59(\mathrm{t}, J=7.4 \mathrm{~Hz}$, $4 \mathrm{H}), 0.47-0.27(\mathrm{~m}, 18 \mathrm{H})$.

3-[4-(2-Ethylhexyl)-4H-cyclopenta[2,1-b:3,4-b']dithiophen-4-yl]propan-1-ol (9). Oxetane $(0.06 \mathrm{~g}, 1.04 \mathrm{mmol})$ was slowly added to a suspension of $\mathrm{LiAlH}_{4}(0.026 \mathrm{~g}, 0.693 \mathrm{mmol})$ in dry MTBE $(10 \mathrm{~mL})$ under inert atmosphere. The reaction mixture was subsequently heated to 50 ${ }^{\circ} \mathrm{C}$ and a solution of 4-(2-ethylhexylidene)-4H-cyclopenta[2,1-b:3,4- $b$ '] dithiophene $(0.100 \mathrm{~g}$, $0.347 \mathrm{mmol})$ in dry MTBE $(2 \mathrm{~mL})$ was added dropwise. The reaction was stirred overnight at $50{ }^{\circ} \mathrm{C} .1 \mathrm{M} \mathrm{HCl}$ solution was then carefully added, followed by diethyl ether $(20 \mathrm{~mL})$, and the organic phase was washed with $\mathrm{NaHCO}_{3}$ and water (2x), dried over anhydrous $\mathrm{MgSO}_{4}$ and filtered. The solvent was removed under reduced pressure and the crude product was purified by column chromatography (silica, eluent petroleum ether:diethyl ether, 60:40) to obtain 3[4-(2-ethylhexyl)-4H-cyclopenta[2,1-b:3,4-b']dithiophen-4-yl]propan-1-ol as a colorless oil (0.079 g, 65\%). ${ }^{1} \mathrm{H} \mathrm{NMR}\left(400 \mathrm{MHz}, \mathrm{CDCl}_{3}\right), \delta(\mathrm{ppm}): 7.12$ (d, J = 4.9 Hz, 2H), $6.91(2 \mathrm{~d}, J=4.9 \mathrm{~Hz}$, $2 \mathrm{H}), 3.39(\mathrm{t}, J=6.5 \mathrm{~Hz}, 2 \mathrm{H}), 1.95-1.84(\mathrm{~m}, 4 \mathrm{H}), 1.27-1.19(\mathrm{br}, 1 \mathrm{H}), 1.09-0.85(\mathrm{~m}, 10 \mathrm{H}), 0.73(\mathrm{t}$, $J=7.0 \mathrm{~Hz}, 3 \mathrm{H}), 0.67-0.60(\mathrm{~m}, 1 \mathrm{H}), 0.57(\mathrm{t}, J=7.4 \mathrm{~Hz}, 3 \mathrm{H}) ;{ }^{13} \mathrm{C} \mathrm{NMR}\left(100 \mathrm{MHz}, \mathrm{CD}_{2} \mathrm{Cl}_{2}\right), \delta(\mathrm{ppm})$ : $158.13,158.07,137.31,137.28,125.10,125.06,122.50,122.47,63.3,42.3,36.0,35.9,34.5$, 29.1, 28.2, 27.7, 23.3, 14.4, 11.0. HRMS (ESI): calcd. for $\mathrm{C}_{20} \mathrm{H}_{28} \mathrm{OS}_{2}[\mathrm{M}+\mathrm{H}]^{+}$: 349.1661, measured: 349.1721.

5-[4-(2-Ethylhexyl)-4H-cyclopenta[2,1-b:3,4-b']dithiophen-4-yl]pentan-2-ol (10). 4-(2Ethylhexylidene)-4H-cyclopenta[2,1- $\left.b: 3,4-b^{\prime}\right]$ dithiophene $(0.100 \mathrm{~g}, 0.347 \mathrm{mmol})$ in dry 2methyltetrahydrofuran (MeTHF, $2 \mathrm{~mL}$ ) was added to a suspension of $\mathrm{LiAlH}_{4}(0.026 \mathrm{~g}, 0.693$ $\mathrm{mmol})$ in dry MeTHF $(10 \mathrm{~mL})$ at $75{ }^{\circ} \mathrm{C}$ under inert atmosphere. The reaction was stirred overnight at $75^{\circ} \mathrm{C} .1 \mathrm{M} \mathrm{HCl}$ solution and diethyl ether $(50 \mathrm{~mL})$ were carefully added and the organic phase was washed with $\mathrm{NaHCO}_{3}$ and water $(2 \times)$, dried over anhydrous $\mathrm{MgSO}_{4}$ and filtered. The solvent was removed under reduced pressure and the crude product was purified by column chromatography (silica, eluent petroleum ether:diethyl ether, 75:25) to obtain 5[4-(2-ethylhexyl)-4H-cyclopenta[2,1-b:3,4-b']dithiophen-4-yl]pentan-2-ol as a light-yellow oil (0.058 g, 44\%). ${ }^{1} \mathrm{H}$ NMR $\left(400 \mathrm{MHz}, \mathrm{CDCl}_{3}\right), \delta(\mathrm{ppm}): 7.13(2 \mathrm{~d}, \mathrm{~J}=4.9 \mathrm{~Hz}, 2 \mathrm{H}), 6.94-6.90(\mathrm{~m}, 2 \mathrm{H})$, $3.68-3.55(\mathrm{~m}, 1 \mathrm{H}), 1.93-1.78(\mathrm{~m}, 4 \mathrm{H}), 1.33-1.18(\mathrm{~m}, 5 \mathrm{H}), 1.01-0.83(\mathrm{~m}, 11 \mathrm{H}), 0.74(\mathrm{t}, J=7.0$ 
$\mathrm{Hz}, 3 \mathrm{H}), 0.66-0.54(\mathrm{~m}, 4 \mathrm{H}) ;{ }^{13} \mathrm{C} \mathrm{NMR}\left(100 \mathrm{MHz}, \mathrm{CDCl}_{3}\right), \delta$ (ppm): 158.01, 157.97, 137.2, 124.89, $124.88,122.34,122.30,122.26,68.3,53.6,42.2$, 30.0, 39.9, 35.7, 34.5, 29.0, 27.7, 23.9, 23.2, 21.1, 14.5, 11.1. HRMS (ESI): calcd. for $\mathrm{C}_{22} \mathrm{H}_{32} \mathrm{OS}_{2}[\mathrm{M}+\mathrm{H}]^{+}: 377.1974$, measured: 377.1953 .

1,3-Dibromo-5-octyl-4H-thieno[3,4-c]pyrrole-4,6(5H)-dione (11). Prepared according to a reported procedure. ${ }^{[42]}$

PCPDTTPD-Br. A mixture of [4-(6-bromohexyl)-4-(2-ethylhexyl)-4H-cyclopenta[2,1-b:3,4$b^{\prime}$ ]dithiophene-2,6-diyl]bis(trimethylstannane) $(0.215 \mathrm{~g}, 0.276 \mathrm{mmol}$ ) and 1,3-dibromo-5octyl-4H-thieno[3,4-c]pyrrole-4,6(5H)-dione $(0.117 \mathrm{~g}, 0.276 \mathrm{mmol})$ was dissolved in a mixture of dry toluene $(4 \mathrm{~mL})$ and dry DMF $(1 \mathrm{~mL})$ and the solution was degassed for 20 min with $\mathrm{N}_{2}$. Subsequently, $\mathrm{Pd}_{2}(\mathrm{dba})_{3}(5.0 \mathrm{mg}, 5.5 \mu \mathrm{mol})$ and $\mathrm{P}(\mathrm{o} \text {-tol })_{3}(6.7 \mathrm{mg}, 22 \mu \mathrm{mol})$ were added and the mixture was heated at reflux overnight. The crude polymer was precipitated in methanol and purified by repetitive soxhlet extractions with acetone, $n$-hexane and chloroform. The chloroform fraction was again precipitated in methanol and filtered, yielding a blue solid (115 $\mathrm{mg}, 58 \%$ ). SEC (THF, $40{ }^{\circ} \mathrm{C}$, PS standards): $M_{\mathrm{n}}=13 \mathrm{~kg} \mathrm{~mol}^{-1}, \ominus=1.5 ; \lambda_{\max }=690 \mathrm{~nm}$.

PCPDTTPD-Im. 1-Methylimidazole $(3 \mathrm{~mL})$ and acetonitrile $(2 \mathrm{~mL})$ were added to PCPDTTPD-Br $\left(115 \mathrm{mg}\right.$ ) and the suspension was placed in a microwave vial and heated for $4 \mathrm{~h}$ at $100{ }^{\circ} \mathrm{C}$. The functionalized polymer was precipitated in diethyl ether and subsequently purified by soxhlet extraction with diethyl ether and methanol. The methanol fraction was again precipitated in diethyl ether and filtered, yielding the functionalized polymer PCPDTTPD-Im as a blue solid (88 mg, 69\%). $\lambda_{\max }=622 \mathrm{~nm}$.

\section{References}

[1] Dennler, G.; Scharber, M. C.; Brabec, C. J. Polymer-Fullerene Bulk-Heterojunction Solar Cells. Adv. Mater. 2009, 21 (13), 1323-1338.

[2] Polman, A.; Knight, M.; Garnett, E. C.; Ehrler, B.; Sinke, W. C. Photovoltaic materials: Present efficiencies and future challenges. Science 2016, 352 (6283), aad4424.

[3] Su, Y. W.; Lan, S. C.; Wei, K. H. Organic Photovoltaics. Mater. Today 2012, 15 (12), 554562.

[4] Dou, L.; You, J.; Hong, Z.; Xu, Z.; Li, G.; Street, R. A.; Yang, Y. 25th Anniversary Article: A Decade of Organic/Polymeric Photovoltaic Research. Adv. Mater. 2013, 25 (46), 6642-6671.

[5] Mazzio, K. A.; Luscombe, C. K. The future of organic photovoltaics. Chem. Soc. Rev. 2015, 44, 78-90.

[6] Darling, S. B.; You, F. The case for organic photovoltaics. RSC Adv. 2013, 3, 17633-17648.

[7] Lizin, S.; Van Passel, S.; De Schepper, E.; Maes, W.; Lutsen, L.; Manca, J.; Vanderzande, D. Life cycle analyses of organic photovoltaics: a review. Energy Environ. Sci. 2013, 6, 3136-3149. [8] Kang, H.; Kim, G.; Kim, J.; Kwon, S.; Kim, H.; Lee, K. Bulk-Heterojunction Organic Solar Cells: Five Core Technologies for Their Commercialization. Adv. Mater. 2016, 28 (36), 7821-7861.

[9] Müllen, K.; Pisula, W. Donor-Acceptor Polymers. J. Am. Chem. Soc. 2015, 137 (30), 95039505.

[10] Vogelbaum, H. S.; Sauvé, G. Recently developed high-efficiency organic photoactive materials for printable photovoltaic cells: a mini review. Synthetic Met. 2017, 223, 107-121.

[11] Hoppe, H.; Sariciftci, N. S. Morphology of polymer/fullerene bulk heterojunction solar cells. J. Mater. Chem. 2006, 16, 45-61. 
[12] Park, S. H.; Roy, A.; Beaupré, S.; Cho, S.; Coates, N.; Moon, J. S.; Moses, D.; Leclerc, M.; Lee, K.; Heeger, A. J. Bulk heterojunction solar cells with internal quantum efficiency approaching 100\%. Nat. Photonics 2009, 3, 297-303.

[13] Holliday, S.; Li, Y.; Luscombe, C. K. Recent advances in high performance donor-acceptor polymers for organic photovoltaics. Prog. Polym. Sci. 2017, 70, 34-51.

[14] Zhao, J.; Li, Y.; Yang, G.; Jiang, K.; Lin, H.; Ade, H.; Ma, W.; Yan, H. Efficient organic solar cells processed from hydrocarbon solvents. Nat. Energy 2016, 1, 15027.

[15] Zhao, W. C.; Li, S.; Yao, H.; Zhang, S.; Zhang, Y.; Yang, B.; Hou, J. Molecular Optimization Enables over 13\% Efficiency in Organic Solar Cells. J. Am. Chem. Soc. 2017, 139 (21), 71487151.

[16] Knupfer, M. Exciton binding energies in organic semiconductors. Appl. Phys. A 2003, 77 (5), 623-626.

[17] Lai, T.-H.; Tsang, S.-W.; Manders, J. R.; Chen, S.; So, F. Properties of interlayer for organic photovoltaics. Mater. Today 2013, 16 (11), 424-432.

[18] Steim, R.; Kogler, F. R.; Brabec, C. J. Interface materials for organic solar cells. J. Mater. Chem. 2010, 20, 2499-2512.

[19] Yin, Z.; Wei, J.; Zheng, Q. Interfacial Materials for Organic Solar Cells: Recent Advances and Perspectives. Adv. Sci. 2016, 3, 1500362.

[20] Lim, K.-G.; Park, S. M.; Woo, H. Y.; Lee, T.-W. Elucidating the Role of Conjugated Polyelectrolyte Interlayers for High-Efficiency Organic Photovoltaics. ChemSusChem 2015, 8, 3062-3068.

[21] Kesters, J.; Govaerts, S.; Pirotte, G.; Drijkoningen, J.; Chevrier, M.; Van den Brande, N.; Liu, X.; Fahlman, M.; Van Mele, B.; Lutsen, L.; Vanderzande, D.; Manca, J.; Clément, S.; Von Hauff, E.; Maes, W. High-Permittivity Conjugated Polyelectrolyte interlayers for HighPerformance Bulk Heterojunction Organic Solar Cells. ACS Appl. Mater. Interfaces 2016, 8 (10), 6309-6314.

[22] He, Z.; Zhong, C.; Huang, X.; Wong, W.-Y.; Wu, H.; Chen, L.; Su, S.; Cao, Y. Simultaneous Enhancement of Open-Circuit Voltage, Short-Circuit Current Density, and Fill Factor in Polymer Solar Cells. Adv. Mater. 2011, 23 (40), 4636-4643.

[23] Kesters, J.; Ghoos, T.; Penxten, H.; Drijkoningen, J.; Vangerven, T.; Lyons, D. M.; Verreet, B.; Aernouts, T.; Lutsen, L.; Vanderzande, D.; Manca, J.; Maes, W. Imidazolium-substituted polythiophenes as efficient electron transport materials improving photovoltaic performance. Adv. Energy Mater. 2013, 3 (9), 1180-1185.

[24] Zhou, H.; Chen, Q.; Li, G.; Luo, S.; Song, T.-B.; Duan, H.-S.; Hong, Z.; You, J.; Liu, Y.; Yang, Y. Photovoltaics. Interface engineering of highly efficient perovskite solar cells. Science 2014, 345 (6196), 542-546.

[25] Zhang, H.; Azimi, H.; Hou, Y.; Ameri, T.; Przybilla, T.; Spiecker, E.; Kraft, M.; Scherf, U.; Brabec, C. J. Improved high-efficiency perovskite planar heterojunction solar cells via incorporation of a polyelectrolyte interlayer. Chem. Mater. 2014, 26, 5190-5193.

[26] Hu, Z.; Zhang, K.; Huang, F.; Cao, Y. Water/alcohol soluble conjugated polymers for the interface engineering of highly efficient polymer light-emitting diodes and polymer solar cells. Chem. Commun. 2015, 51, 5572-5585.

[27] Chen, L.-M.; Xu, Z.; Hong, Z.; Yang, Y. Interface investigation and engineering - achieving high performance polymer photovoltaic devices. J. Mater. Chem. 2010, 20, 2575-2598.

[28] Houston, J. E.; Richeter, S.; Clément, S.; Evans, R. C. Molecular design of interfacial layers based on conjugated polythiophenes for polymers and hybrid solar cells. Polym. Int. 2017, 66 (10), 1333-1348. 
[29] Seo, J. H.; Gutacker, A.; Sun, Y.; Wu, H.; Huang, F.; Cao, Y.; Scherf, U.; Heeger, A. J.; Bazan, G. C. Improved high-efficiency organic solar cells via incorporation of a conjugated polyelectrolyte interlayer. J. Am. Chem. Soc. 2011, 133 (22), 8416-8419.

[30] Zilberberg, K.; Behrendt, A.; Kraft, M.; Scherf, U.; Riedl, T. Ultrathin interlayers of a conjugated polyelectrolyte for low work-function cathodes in efficient inverted organic solar cells. Org. Electron. 2013, 14, 951-957.

[31] Min, J.; Zhang, H.; Stubhan, T.; Luponosov, Y. N.; Kraft, M.; Ponomarenko, S. A.; Ameri, T.; Scherf, U.; Brabec, C. J. A combination of Al-doped $\mathrm{ZnO}$ and a conjugated polyelectrolyte interlayer for small molecule solution-processed solar cells with an inverted structure. J. Mater. Chem. A 2013, 1, 11306-11311.

[32] Zhang, W.; Li, Y.; Zhu, L.; Liu, X.; Song, C.; Li, X.; Sun, X.; Fang, J. PTB7-based narrow bandgap conjugated polyelectrolyte as an efficient cathode interlayer in PTB7-based polymer solar cells. Chem. Commun. 2017, 53, 2005-2008.

[33] Hu, L.; Wu, F.; Li, C.; Hu, A.; Hu, X.; Zhang, Y.; Chen L.; Chen, Y. Alcohol-Soluble n-Type Conjugated Polyelectrolyte as Electron Transport Layer for Polymer Solar Cells. Macromolecules 2015, 48 (16), 5578-5586.

[34] Henson, Z. B.; Zhang, Y.; Nguyen, T.-Q.; Seo, J. H.; Bazan, G. C. Synthesis and properties of two cationic narrow band gap conjugated polyelectrolytes. J. Am. Chem. Soc. 2013, 135 (11), 4163-4166.

[35] Mai, C.-K.; Zhou, H.; Zhang, Y.; Henson, Z. B.; Nguyen, T.-Q.; Heeger, A. J.; Bazan, G. C. Facile doping of anionic narrow-band-gap conjugated polyelectrolytes during dialysis. Angew. Chem. Int. Ed. 2013, 52, 12874-12878.

[36] Page, Z. A.; Liu, F.; Russell T. P.; Emrick, T. Tuning the energy gap of conjugated polymer zwitterions for efficient interlayers and solar cells. J. Polym. Sci., Part A: Polym. Chem. 2015, $53(2), 327-336$.

[37] Zhou, H; Zhang, Y.; Mai, C.-K.; Collins, S. D.; Nguyen, T.-Q.; Bazan G. C.; Heeger, A. J. Conductive Conjugated Polyelectrolyte as Hole-Transporting Layer for Organic Bulk Heterojunction Solar Cells. Adv. Mater. 2013, 26 (5), 780-785.

[38] Kawabata, K.; Takeguchi, M.; Goto, H. Optical Activity of Heteroaromatic Conjugated Polymer Films Prepared by Asymmetric Electrochemical Polymerization in Cholesteric Liquid Crystals: Structural Function for Chiral Induction. Macromolecules 2013, 46 (6), 2078-2091.

[39] Shi, J.; Zhao, W.; Xu, L.; Kan, Y.; Li, C.; Song, J.; Wang, H. Small Molecules of Cyclopentadithiophene Derivatives: Effect of Sulfur Atom Position and Substituted Groups on Their UV-Abs Properties. J. Phys. Chem. C 2014, 118 (15), 7844-7855.

[40] Vanormelingen, W.; Verstappen, P.; Maes, V.; Bevk, D.; Lutsen, L.; Vanderzande, D.; Maes, W. Synthetic routes toward asymmetrically substituted (functionalized) $4 \mathrm{H}$-cyclopenta[2,1$b: 3,4-b^{\prime}$ ]dithiophenes. Synlett 2013, 24 (18), 2389-2392.

[41] Kudla, C. J.; Dolfen, D.; Schottler, K. J.; Koenen, J.-M.; Breusov, D.; Allard, S.; Scherf, U. Cyclopentadithiazole-Based Monomers and Alternating Copolymers. Macromolecules 2010, 43 (18), 7864-7867.

[42] Piliego, C.; Holcombe, T. W.; Douglas, J. D.; Woo, C. H.; Beaujuge, P. M.; Fréchet, J. M. J. Synthetic Control of Structural Order in N-Alkylthieno[3,4-c]pyrrole-4,6-dione-Based Polymers for Efficient Solar Cells. J. Am. Chem. Soc. 2010, 132 (22), 7595-7597.

[43] Danley, R. L.; Caulfield, P. A.; Aubuchon, S. R. A rapid-scanning differential scanning calorimeter. Am. Lab. 2008, 40, 9-11. 
[44] Pirotte, G.; Kesters, J.; Verstappen, P.; Govaerts, S.; Manca, J.; Lutsen, L.; Vanderzande, D.; Maes, W. Continuous Flow Polymer Synthesis toward Reproducible Large-Scale Production for Efficient Bulk Heterojunction Organic Solar Cells. ChemSusChem 2015, 8 (19), 3228-3233. [45] Trasatti, S. The Absolute Electrode Potential: an Explanatory Note. Pure Appl. Chem. 1986, 58 (7), 955-966.

[46] Bard, J.; Faulkner, L. R. Electrochemical Methods: Fundamentals and Applications, 2nd Ed., 2001, Wiley. 